\title{
Urocortin 2-Deficient Mice Exhibit Gender-Specific Alterations in Circadian Hypothalamus-Pituitary-Adrenal Axis and Depressive-Like Behavior
}

\author{
Alon Chen, ${ }^{1}$ Eric Zorrilla, ${ }^{2}$ Sean Smith, ${ }^{1}$ David Rousso, ${ }^{1}$ Coree Levy, ${ }^{2}$ Joan Vaughan, ${ }^{1}$ Cindy Donaldson, ${ }^{1}$ \\ Amanda Roberts, ${ }^{1}$ Kuo-Fen Lee, ${ }^{1}$ and Wylie Vale ${ }^{1}$ \\ ${ }^{1}$ Clayton Foundation Laboratories for Peptide Biology, The Salk Institute, La Jolla, California 92037, and 2Department of Neuropharmacology, The Scripps \\ Research Institute, La Jolla, California 92037
}

Gender differences in hypothalamus-pituitary-adrenal (HPA) axis activation and the prevalence of mood disorders are well documented. Urocortin 2, a recently identified member of the corticotropin-releasing factor family, is expressed in discrete neuroendocrine and stress-related nuclei of the rodent CNS. To determine the physiological role of urocortin 2, mice null for urocortin 2 were generated and HPA axis activity, ingestive, and stress-related behaviors and alterations in expression levels of CRF-related ligands and receptors were examined. Here we report that female, but not male, mice lacking urocortin 2 exhibit a significant increase in the basal daily rhythms of ACTH and corticosterone and a significant decrease in fluid intake and depressive-like behavior. The differential phenotype of urocortin 2 deficiency in female and male mice may imply a role for urocortin 2 in these gender differences.

Key words: urocortin 2; CRF/CRH; depression; gender differences; stress; HPA axis

\section{Introduction}

The hypothalamic neuropeptide corticotropin-releasing factor (CRF) plays an important and well established role in the regulation of the hypothalamus-pituitary-adrenal (HPA) axis under basal and stress conditions (Vale et al., 1981; Rivier and Vale, 1983). In addition to its hypophysiotropic action, CRF is proposed to integrate the endocrine, autonomic, and behavioral responses to stressors (Sutton et al., 1982; Koob and Heinrichs, 1999). CRF and its receptors are implicated in the control of arousal, anxiety, cognitive functions, and appetite (for review, see Arborelius et al., 1999; Bale and Vale, 2004; Zorrilla and Koob, 2004). Dysregulation of the stress response can have severe psychological and physiological consequences (de Kloet et al., 2005), and chronic hyperactivation of the CRF system has been linked to stress-related emotional disorders such as anxiety, anorexia nervosa, and melancholic depression (for review, see Chrousos and Gold, 1992; Holsboer, 1999; Holmes et al., 2003).

Gender differences in HPA axis activation and the prevalence of mood disorders also are well documented (Rhodes and Rubin, 1999; Piccinelli and Wilkinson, 2000). Pronounced gender differences exist in both basal circadian rhythm and stress-induced

Received Sept. 19, 2005; revised March 19, 2006; accepted April 10, 2006.

This work is supported by National Institute of Diabetes and Digestive and Kidney Diseases Program Project Grant DK 26741, The Robert J. and Helen C. Kleberg Foundation, The Adler Foundation, and the Foundation for Research (W.V.). W.V. is a Senior Foundation for Research Investigator.

Correspondence should be addressed to Dr. Wylie Vale, Clayton Foundation Laboratories for Peptide Biology, The Salk Institute for Biological Studies, 10010 North Torrey Pines Road, La Jolla, CA 92037. E-mail: vale@salk.edu.

A. Chen's present address: Department of Neurobiology, Weizmann Institute of Science, Rehovot, Israel 76100. E-mail: alon.chen@weizmann.ac.il.

DOI:10.1523/JNEUROSCI.3955-05.2006

Copyright $\odot 2006$ Society for Neuroscience $\quad$ 0270-6474/06/265500-11\$15.00/0 activation of the HPA axis. Females exhibit a higher plasma concentration of ACTH and corticosterone throughout daily rhythms and a greater magnitude and duration of HPA response to different stressors (Rhodes and Rubin, 1999).

Peptides encoded by the urocortin 2 (Ucn-2) gene, also known as the stresscopin-related gene, were identified as new members of the CRF family (Hsu and Hsueh, 2001; Reyes et al., 2001). In addition to CRF and Ucn-2 peptides, the mammalian CRFpeptide family includes Ucn-1 (Vaughan et al., 1995) and peptides encoded by the Ucn-3, or stresscopin (Hsu and Hsueh, 2001; Lewis et al., 2001), gene. Transcripts encoding Ucn-2 are expressed in discrete regions of the rodent CNS that position it to be a potential modulator of neuroendocrine activity and stressrelated behavior, including the paraventricular (PVN), supraoptic (SON), and arcuate nuclei in the hypothalamus and locus ceruleus in the brainstem (Reyes et al., 2001). The effects of CRFrelated peptides are mediated through activation of two known receptors, CRF receptor 1 (CRFR1) (Chen et al., 1993), and CRFR2 (Kishimoto et al., 1995; Lovenberg et al., 1995; Perrin et al., 1995; Stenzel et al., 1995) with distinct distributions in the CNS (Van Pett et al., 2000), implying diverse physiological functions. Amidated 38 amino acid synthetic peptides that encode the $\mathrm{C}$ terminus of human or mouse preproUcn-2 selectively bind and activate CRFR2 with high affinity, suggesting that mature Ucn-2 peptide may be an endogenous CRFR2 agonist. Because many endogenous ligands have affinity for CRFR2 (Ucn-1, Ucn-2, Ucn-3, and, to a lesser degree, CRF), it has been difficult to attribute stress-related functions to individual CRF family peptides using receptor knock-out $(\mathrm{KO})$ and pharmacological models.

To determine the physiological role of Ucn-2, here we generated mice deficient for Ucn-2 (Ucn-2 KO). The basal and stress- 
induced activation of HPA axis activity, stress-related behaviors, and alterations in the expression levels of CRF-related ligands and receptors in male and female mice and their wild-type (WT) littermates are presented.

\section{Materials and Methods}

Construction of Ucn-2-null mice. A genomic DNA clone containing the Ucn-2 locus was isolated, and a targeting construct in which the Ucn-2 coding sequence was replaced with a neomycin-resistant gene cassette was generated as described in Fig. $2 a$. Embryonic stem (ES) cell cultures were established, and positive ES clones were injected into C57BL/6 blastocysts to generate chimeric mice as described previously (Smith et al., 1998). Chimeras were mated to produce heterozygous mutant mice on a mixed C57BL/6 and 129 genetic background. Breeding of these mice was then continued and maintained via heterozygote $\times$ heterozygote nonsibling matings. Mutant mice are fertile, and the mutant allele was transmitted in a Mendelian manner. Animal protocols were approved by the Institutional Animal Care and Use Committees of The Salk Institute and The Scripps Research Institute.

$R N A$ preparation and semiquantitative reverse transcription- $P C R$. Total RNA was extracted from the brain, skeletal muscle, and skin of Ucn-2 null mice and WT littermates. Total RNA was isolated using the Trizol RNA reagent (Molecular Research Center, Cincinnati, $\mathrm{OH}$ ) based on the acid guanidinium thiocyanate-phenol-chloroform extraction method according to the recommendations of the manufacturer. To avoid falsepositive results caused by DNA contamination, we performed a DNase treatment for $30 \mathrm{~min}$ at $37^{\circ} \mathrm{C}$ using the RQ1 RNase-free DNase (Promega, Madison, WI). We used semiquantitative reverse transcription (RT)-PCR to amplify the levels of endogenous Ucn-2 present in the tissues studied. The expression of the ribosomal protein S16 served as internal control. The PCR conditions were as follows: cDNA equivalent to 200 ng of total RNA was amplified by PCR for 35 cycles at an annealing temperature of $60^{\circ} \mathrm{C}$. The final $\mathrm{MgCl}_{2}$ concentration was $3 \mathrm{~mm}$, and each reaction contained $2.5 \mathrm{U}$ of TaqDNA polymerase (BIO-X-ACT DNA polymerase; Bioline, London, UK).

Immunohistochemistry. Adult Ucn-2 null mice and WT littermates were anesthetized with chloral hydrate $(350 \mathrm{mg} / \mathrm{kg}$, i.p.) and perfused with $4 \%$ paraformaldehyde fixative. Frontal $25-\mu$ m-thick sections throughout the brain were prepared for avidin-biotin-immunoperoxidase localization of mouse Ucn-2 immunoreactivity using Vectastain Elite reagents (Vector Laboratories, Burlingame, CA). Rabbit antiserum against mouse Ucn-2, produced and characterized by our laboratory (Chen et al., 2004), was used at a final dilution of 1:4000. Specificity of immunostaining was evaluated using primary antisera preincubated overnight at $4^{\circ} \mathrm{C}$ with $0-300 \mu \mathrm{M}$ synthetic Ucn-2.

Ovariectomy, blood collection, and hormone analysis. Ovariectomy (OVX) was performed through a dorsal incision under isoflurane anesthesia 2 weeks before blood collection. For ACTH and corticosterone analyses, we used individually housed, 10- to 12-week-old male or female mice. Blood samples were collected by retro-orbital eye bleed from unanesthetized animals within $15 \mathrm{~s}$ of disturbance of the cage. Basal morning samples were collected at 7:00 A.M. and basal evening samples were collected at 5:00 P.M., both from mice held on a $12 \mathrm{~h}$ light/dark photoperiod (light on at 6:00 A.M.). The $24 \mathrm{~h}$ corticosterone profile samples were obtained from mice housed on a reverse cycle room held on a $12 \mathrm{~h}$ light/dark photoperiod (light on at 10:00 P.M. is equivalent to Zeitgeber time $0000 \mathrm{~h}$ ). For evaluation of the endocrine response to stress, we collected blood samples immediately after 2 or $10 \mathrm{~min}$ of restraint stress induced using a $50 \mathrm{ml}$ plastic conical tube with the bottom removed. For each experiment, individual animals were bled only once. Plasma samples were immediately centrifuged and stored at $-20^{\circ} \mathrm{C}$ until assays for measurement hormones were conducted. Corticosterone was quantified in duplicate samples using a commercially available double antibody RIA kit (MP Biomedicals, Irvine, CA) as per the directions of the manufacturer. ACTH was measured (50 $\mu$ l of plasma) using a commercially available two-site immunoassay (Nichols Institute Diagnostics, San Juan Capistrano, CA).

In situ hybridization. Animals were rapidly decapitated, and whole brains were removed and frozen on dry ice. Coronal sections $(20 \mu \mathrm{m})$ were cut on a cryostat, thaw mounted onto glass slides, and stored at $-80^{\circ} \mathrm{C}$ until use. Antisense cRNA probes were transcribed from linearized cDNA templates corresponding to CRF1 (455 bp), CRF2 (461 bp), CRF (1200 bp), Ucn-1 (600 bp), Ucn-3 (528 bp), and arginine vasopres$\sin$ (AVP) (700 bp). [ ${ }^{35} \mathrm{~S}$ ]UTP (PerkinElmer, Emeryville, CA) was incorporated into cRNA probes during transcription, and specific activity of the probes was determined to be $\sim 2 \times 10^{8} \mathrm{dpm} / \mu \mathrm{g}$ cRNA. The saturating concentration for the probes used for assays was $0.3 \mu \mathrm{g} \cdot \mathrm{ml}^{-} \cdot \mathrm{kb}^{-1}$.

The procedure used for in situ hybridization was as described previously ( $\mathrm{Li}$ et al., 2002). Briefly, brain sections were fixed in $4 \%$ paraformaldehyde and treated with $0.25 \%$ acetic anhydride in $0.1 \mathrm{M}$ triethanolamine, $\mathrm{pH} 8.0$, followed by a rinse in $2 \%$ SSC, dehydrated through a graded series of alcohols, delipidated in chloroform, rehydrated through a second series of alcohols, and then air dried. The slides were then exposed to cRNA probes overnight in humidified chambers at $55^{\circ} \mathrm{C}$. After incubation, the slides were washed in SSC of increasing stringency, in RNase, and then in $0.1 \% \mathrm{SSC}$ at $63^{\circ} \mathrm{C}$, dehydrated through a graded series of alcohols, and dried. Slides were dipped in NTB-2 emulsion (Eastman Kodak, Rochester, NY), exposed from 7 to $14 \mathrm{~d}$ at $4^{\circ} \mathrm{C}$, and developed. After development, the slides were counterstained with cresyl violet.

Autoradiograms for in situ hybridization were visualized under darkfield illumination using a E600 light microscope (Nikon, Tokyo, Japan) and analyzed with Image-Pro Plus imaging software (Media Cybernetics, San Diego, CA). Integrated density values of hybridized neurons of each side of the nuclei of interest were measured in at least five consecutive sections for each animal, with four mice per group. Nonlinearity of radioactivity in the emulsion was evaluated by comparing density values with a calibration curve created from autoradiograms of known dilutions of the radiolabeled probes immobilized on glass slides in $2 \%$ gelatin fixed with $4 \%$ paraformaldehyde and exposed and developed simultaneously with the in situ hybridization autoradiograms. All images were captured using a digital camera (Photometrics, Huntington Beach, CA) and Image-Pro Plus imaging software (Media Cybernetics). The images were cropped and adjusted to balance brightness and contrast in Adobe Photoshop (version 5.5; Adobe Systems, San Jose, CA) before import into Canvas (version 6.0) for assembly into plates.

Food and water intake. Mature mice (average weights of 29-37 and $27-32 \mathrm{~g}$ for males and females, respectively) were individually housed in Plexiglas test cages $(15 \times 15 \times 18 \mathrm{~cm})$ for daily $23.5 \mathrm{~h}$ sessions. Cages had a wire-mesh floor and were located in ventilated, sound-attenuating enclosures equipped with a $1.1 \mathrm{~W}$ miniature bulb to provide a $12 \mathrm{~h}$ light/ dark cycle, and test sessions began at the onset of the dark cycle. Subjects were allowed to obtain nose-poke-contingent [fixed ratio 2 (FR2); $0.5 \mathrm{~s}$ nose poke] $20 \mathrm{mg}$ Formula A/I pellets $(60.0 \%$ carbohydrate, $3.7 \%$ fat, $24.1 \%$ protein, $7.0 \%$ ash, $5.2 \%$ moisture, $370 \mathrm{cal} / 100 \mathrm{~g}$; P. J. Noyes Company, Lancaster, NH) from a pellet dispenser (Med Associates, St. Albans, VT) or $35 \mu \mathrm{l}$ water aliquots from an external syringe pump (Razel Scientific Instruments, Stamford, CT) into separate reservoirs located adjacent to the nose-poke holes. Nose-poke holes $(0.9 \mathrm{~cm}$ in diameter; $7.5 \mathrm{~cm}$ apart; $1.5 \mathrm{~cm}$ from the grid floor) were situated on the same wall of the cage and were equipped with infrared photobeams monitored by an IBM personal computer-compatible microcomputer with $10 \mathrm{~ms}$ resolution. The food trough was situated $4 \mathrm{~cm}$ from its nose-poke hole and $1.2 \mathrm{~cm}$ from the grid floor. The water reservoir was located $2 \mathrm{~cm}$ from its nosepoke hole and $3 \mathrm{~cm}$ from the grid floor. To acclimate mice fully to the test apparatus and procedures, they were first allowed to respond for food or water $(100 \mu \mathrm{l})$ on an FR1 schedule. The unit volume of water delivery was decreased (50 $\mu \mathrm{l}, 35 \mu \mathrm{l}$ ), and response requirement was increased (FR2) over a 3 week period when a mouse achieved stable ( $\pm 15 \%$ for $3 \mathrm{~d})$, free feeding-like levels of food and water intake at each milestone. An FR2 schedule was used to reduce unintended food or water delivery secondary to exploratory nose poking. Spillage of pellets is $0.6 \pm 0.1 \%$ of the total responses for food under these test conditions ( $n=27$ sessions). These procedures allow study of spontaneous feeding- and drinkingdirected behaviors in nondeprived mice with excellent quantitative and temporal resolution.

Male and female mice $(n=6-8$ per genotype) were first tested for 


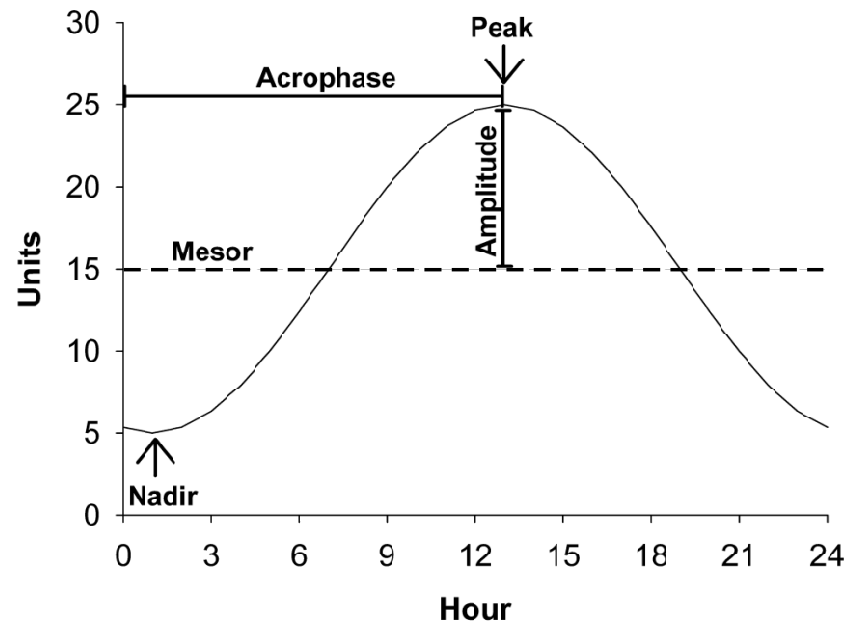

Figure 1. For clarity, cosinor measures (e.g., MESOR, amplitude, and acrophase) of circadian regulation of drug and food intake are illustrated in a sample figure that depicts a cosinor function with MESOR of $15 \mathrm{~h}$, amplitude of $10 \mathrm{~h}$, peak of $25 \mathrm{~h}$, nadir of $5 \mathrm{~h}$, and acrophase of $13 \mathrm{~h}$ from a reference point (e.g., dark onset).

daily spontaneous intake and subsequently for differences in ingestive responses to food deprivation, a mild stressor (subcutaneous isotonic saline injection, $10 \mathrm{ml} / \mathrm{kg}$ ), and $d$-fenfluramine ( $2 \mathrm{mg} / \mathrm{kg}$, i.p.), an indirect serotonin agonist. Each challenge was tested in a within-subject, counterbalanced design, relative to an untreated baseline (for food deprivation and injection stress) or vehicle (for $d$-fenfluramine) control condition with 6 intervening treatment-free days between test days. To quantify the circadian regulation of food, water, and drug intake, cosinor analysis was performed as described previously (Chen et al., 2006). Cosinor analysis, a form of chronobiologic analysis, is superior to atheoretical repeated-measures ANOVA of intake across a $24 \mathrm{~h}$ period because cosinor analysis explicitly models the known circadian regulation of intake. This allows comparison of the degree to which intake is still regulated in a circadian manner, as well as how individual attributes of the circadian rhythm change, resulting in local differences in ingestion (Smolensky et al., 1976; Lentz, 1990). Circadian analysis was especially appropriate given the change in corticosterone circadian peak levels observed in female mice. Cosinor analysis is a form of time-series analysis that models chronobiologic rhythms as a cosine function with the following attributes: the midline estimating statistic of rhythm (MESOR; mean level around which the cosine function oscillates), amplitude [the distance from the MESOR to the extremes (peak or nadir) of the oscillation], acrophase (the time at which the cosine peak occurs relative to a time of interest, in this case the start of the session), and period (the time interval at which the cycle repeats) (for illustration, see Fig. 1).

To examine changes in circadian regulation, a predefined period of $24 \mathrm{~h}$ was used according to the following formula:

$$
y=\operatorname{MESOR}+\text { amplitude } \times \cos \left(\frac{2 \pi(x-\text { acrophase })}{24}\right)
$$

Cosinor functions were fit individually to each mouse's daily intakes, and the MESOR, amplitude, acrophase, and goodness of fit were obtained from each and averaged across rats. Peaks were calculated as the (MESOR + amplitude), and nadirs were calculated as the (MESOR - amplitude). Because food and water intake occur in discrete episodes ("meals"), intake was cumulated into $3 \mathrm{~h}$ bins to better model the underlying intake rhythm. The first and last hours of the $23 \mathrm{~h}$ data collection period were not used for curve fitting because of confounding influences of recent or anticipated removal from the test cage for daily maintenance. DataFit 8.0 (Oakdale Engineering, Oakdale, PA) was used for curve fitting.

Locomotor activity. Locomotor activity of male and female WT and Ucn-2 null mice was examined across $28 \mathrm{~h}(n=12)$, which included a $4 \mathrm{~h}$ habituation period at the end of the dark (active) phase, followed by a standard $12 \mathrm{~h}$ light (inactive)/dark phase. Testing took place in Plexiglas cages $(42 \times 22 \times 20 \mathrm{~cm})$ placed into frames $(25.5 \times 47 \mathrm{~cm})$ and mounted with two levels of photocell beams at 2 and $7 \mathrm{~cm}$ above the bottom of the cage (San Diego Instruments, San Diego, CA). These two sets of beams allowed for the recording of both horizontal (locomotion) and vertical (rearing) behavior. A thin layer of bedding material was added to the bottom of the cage. Food pellets were scattered evenly across the bottom of the cage, and a waterspout was extended down into the cage just above the level of the vertical beams. Mice were placed in the activity boxes for the final $3 \mathrm{~h}$ of their light (inactive) cycle to habituate them to the testing environment.

Forced-swim test. Forced-swim test (FST) sessions were conducted using a longer test period ( $15 \mathrm{~min}$ ) and larger diameter cylinder than that originally used by Porsolt et al. (1977), modifications that increase the sensitivity and specificity of detecting antidepressant-like effects in mice (Sunal et al., 1994). For testing, mice were placed in individual, clear polypropylene cylinders ( $38 \mathrm{~cm}$ tall, $27 \mathrm{~cm}$ diameter; Cambro, Huntington Beach, CA) containing $23-25^{\circ} \mathrm{C}$ water, $15 \mathrm{~cm}$ deep to prevent the mouse's tail from touching the cylinder bottom (Detke et al., 1995; Detke and Lucki, 1996). The water was changed between subjects. Test sessions were recorded by a video camera positioned directly above the cylinders, and videotapes were scored by a trained observer naive to genotype using a previously validated time-sampling method in which the presence of immobility, swimming, or climbing was scored at $5 \mathrm{~s}$ intervals (Detke et al., 1995). Antidepressants with a proximate serotonergic mechanism of action decrease immobility by increasing swimming behavior, whereas noradrenergic-acting antidepressants do so by increasing climbing behavior (Detke et al., 1995). Male $(n=11 \mathrm{WT}$ and 10 null) and female ( $n=12 \mathrm{WT}$ and 10 null) mice were tested under room lighting in separate sessions during the middle third of the dark cycle.

Tail-suspension test. Mice were suspended by the end of their tail to a bar that was $35 \mathrm{~cm}$ above the floor with adhesive tape. At the end of each videotaped 6 min trial $(n=12)$, the duration of total immobility was scored. Antidepressants decrease the duration of immobility in this model (Cryan et al., 2005).

Elevated plus maze. Male and female Ucn-2 null mice and their WT littermates, 12-14 weeks of age, were used. The elevated plus maze apparatus and experimental conditions were as described previously (Smith et al., 1998). The number of entries into and the time spent on the open arms were expressed as a percentage of the total number of arm entries and test duration, respectively. Anxiolytic and anxiogenic drugs, respectively, increase and decrease relative exploration of the open arms (Lister, 1987).

Light/dark transfer test. The light/dark transfer test takes advantage of the natural conflict of a rodent between the exploration of a novel environment and the aversive properties of a large, brightly lit open field. A greater amount of time in the light compartment and a greater number of transitions are indicative of decreased anxiety-like behavior (Bourin and Hascoet, 2003). The test apparatus is a rectangular Plexiglas box divided by a partition into two environments. One compartment $(14.5 \times 27 \times$ $26.5 \mathrm{~cm})$ is dark (15-25 lux), and the other compartment $(28.5 \times 27 \times$ $26.5 \mathrm{~cm}$ ) is highly illuminated (1000-1100 lux) by a $60 \mathrm{~W}$ light source located above it. The compartments are connected by an opening $(7.5 \times$ $7.5 \mathrm{~cm}$ ) located at the floor level in the center of the partition. The mice were placed in the dark compartment to initiate the test session. Behavior was recorded using a camera mounted above the apparatus. The time spent in each compartment and the number of transitions between compartments was measured. All four paws were required to be in a compartment for it to be counted. Each mouse was tested in a single $5 \mathrm{~min}$ session during the dark phase of the circadian cycle.

Cued and contextual fear conditioning. In this procedure, mice learn to associate a novel environment (context) and a previously neutral stimulus (conditioned stimulus, a tone) with an aversive footshock stimulus. Testing then occurs in the absence of the aversive stimulus. Conditioned animals, when exposed to the conditioned stimuli, tend to refrain from all but respiratory movements by freezing. Freezing responses can be triggered by exposure to either the context in which the shock was received (context test) or the conditioned stimulus. Conditioning took place in a Freeze Monitor chamber (San Diego Instruments) housed in a sound-proof box. The conditioning chamber $(26 \times 26 \times 17 \mathrm{~cm})$ was 
a.

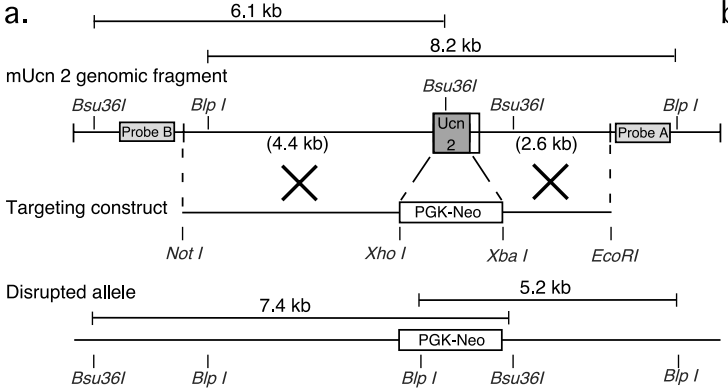

b. PCR
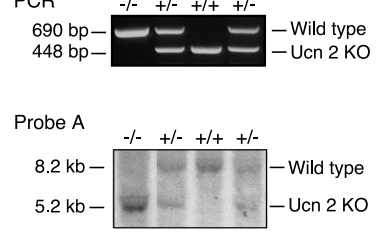

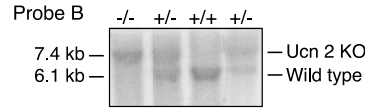

C.

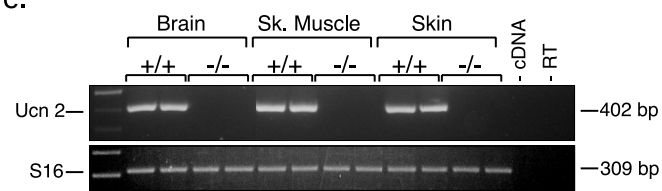

d.

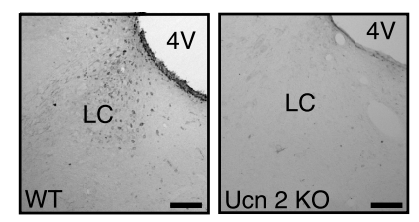

Figure 2. Generation of Ucn-2-deficient mice. $\boldsymbol{a}$, Structure of the Ucn-2 locus (top), targeting vector used to transfect ES cells (middle), and the mutated locus (bottom). $\boldsymbol{b}$, Southern blot and PCR analysis of tail DNA isolated from the progeny of a heterozygote cross (wild-type, $+/+$; heterozygous, $+/-$; and null mutant, $-/-$ ). c, RT-PCR assay demonstrated the absence of Ucn-2 mRNA in the brain, skeletal muscle, and skin of the Ucn-2 mutant mice. $\boldsymbol{d}$, Immunohistochemistry demonstrated the absence of $U c n-2$ protein in the locus ceruleus (LC) of $U c n-2$ mutant mice. $4 \mathrm{~V}$, Fourth ventricle.

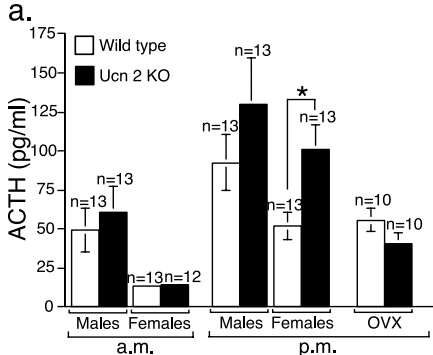

C.

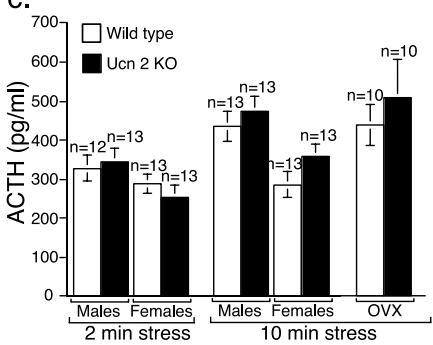

b.

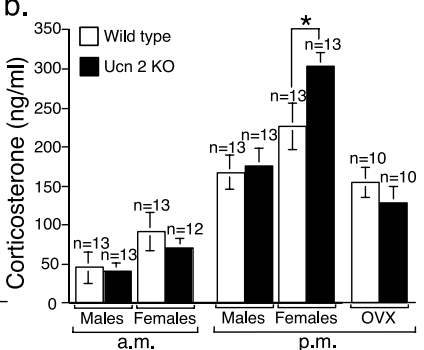

d.

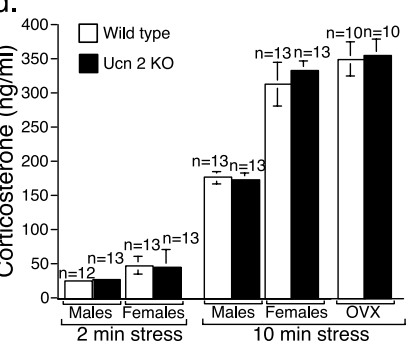

Figure 3. Higher nocturnal basal (prestress) ACTH and corticosterone levels in female Ucn-2 null mutant mice. $\boldsymbol{a}, \boldsymbol{b}$, Basal (prestress) ACTH ( $\boldsymbol{a}$ ) and corticosterone $(\boldsymbol{b})$ plasma levels at 7:00 A.M. (a.m.) and 5:00 P.M. (p.m.) in male and female Ucn-2 mutant mice and WT littermates. c, $\boldsymbol{d}$, Plasma concentrations of ACTH (c) and corticosterone (d) in Ucn-2 null mice and WT littermates after 2 or 10 min of restraint stress. Note that $U c n-2$ mutant mice show normal hormonal responses to acute restraint stress. Data are displayed as the mean \pm SEM. ${ }^{*} p<0.05$ vs WT mice.

made of Plexiglas with a speaker and light mounted on two opposite walls. The chamber was installed with a shockable grid floor. On day 1 , mice were placed in the conditioning chamber for $10 \mathrm{~min}$ to habituate them to the apparatus. On day 2, the mice were exposed to the context and conditioned stimulus (sound, $30 \mathrm{~s}, 3000 \mathrm{~Hz}, 80 \mathrm{~dB}$ ) in association with foot shock (scrambled current, $0.70 \mathrm{~mA}, 2 \mathrm{~s}$ ). Specifically, a $5.5 \mathrm{~min}$ session was run in which the mice received two shock exposures, both in the last $2 \mathrm{~s}$ of a $30 \mathrm{~s}$ tone exposure. On day 3 , contextual conditioning (as determined by freezing behavior) was measured in a 5 min test in the chamber where the mice were trained (context test). The mice were tested for cued conditioning $2-4 \mathrm{~h}$ after this test. For this test, the mice were placed in a novel context for $3 \mathrm{~min}$, after which they were exposed to the conditioned stimulus (tone) for $3 \mathrm{~min}$. For this test, the chamber was disguised with new walls (black opaque plastic creating a triangular-shaped compartment in contrast to a clear plastic square compartment), a new floor (black opaque plastic in contrast to metal grid), and a novel odor (drop of orange extract under the floor). Freezing behavior, i.e., the absence of all voluntary movements except breathing, was measured in 5 min intervals in all four sessions (habituation, conditioning, context test, and conditioned stimulus) by a validated computer-controlled recording of photocell beam interruptions (Contarino et al., 2002) Freezing behavior in each test is indicative of the formation of an association between the particular stimulus (either the environment or the tone) and the shock, i.e., that learning has occurred.

Statistical analysis. ANOVA and $t$ tests were used to identify statistically significant differences. To determine the effect of $U c n-2$ deficiency on food and water intake across the day, $t$ tests were performed on measures obtained from cosinor analyses, and split-plot ANOVA was performed on raw intake in $3 \mathrm{~h}$ bins or the water/ food ratio in $6 \mathrm{~h}$ bins, with genotype as a betweensubject factor and time bin as a repeated measure. To determine the effect of fenfluramine or injection stress on ingestion, split-plot ANOVAs were performed with treatment and time as within-subject factors and genotype as a betweensubject factor. To determine the effect of $U c n-2$ deficiency on forcedswim immobility, split-plot ANOVAs were performed with genotype as a between-subject factor and time bin (1-5, 6-10, and 11-15) as a repeated measure. Significant differences in immobility were further interpreted by comparing swimming and climbing of $U c n-2 \mathrm{KO}$ mice with the control distribution as $z$-scores. Differences in tail-suspension immobility were determined using Student's $t$ test. For post hoc interpretation of ANOVA effects having more than two levels, Dunnett's test was used, and Student's $t$ tests were used for factors having only two levels. The software packages used were Systat 10.0 (SPSS, Chicago, IL) and InStat 3.0 (GraphPad Software, San Diego, CA).

\section{Results}

\section{Generation of $U c n$-2-deficient mice}

To generate mice deficient for Ucn-2, a genomic DNA clone containing $U c n-2$ was isolated, and a targeting construct in which the full $U c n-2$ coding sequence was replaced with a neomycinresistant gene cassette was constructed (Fig. $2 a$ ). J1 ES cells were electroporated with the targeting construct, and positive ES clones were selected as described previously (Smith et al., 1998). Targeted ES cells were injected into C57BL/6 mice blastocysts to generate chimeric mice, which transmitted the null mutation through the germ line. Germ-line transmission of the disrupted allele was confirmed by Southern blot analysis, using both $3^{\prime}$ (probe A) or 5' (probe B) probes (Fig. $2 b$ ). To determine whether the targeted deletion resulted in a null mutation of Ucn-2, we performed RT-PCR and immunohistochemical staining and determined that Ucn-2 mRNA (Fig. $2 c$ ) and peptide (Fig. $2 d$ ) were undetectable in $U c n-2$ mutant mice. These results demonstrate that the disruption of $U \mathrm{cn}-2$ resulted in a null mutation in these mice. Mutant mice are fertile, and the mutant allele was transmitted in a Mendelian manner. Cresyl violet (Nissl) staining of brain sections revealed no apparent cytoarchitectural abnormalities in the mutant mice (data not shown).

\section{Higher basal ACTH and corticosterone levels in female Ucn-2} mutant mice

Because Ucn-2 is expressed in neuroendocrine and stress-related cell groups in the mouse hypothalamus, major regulatory sites of 

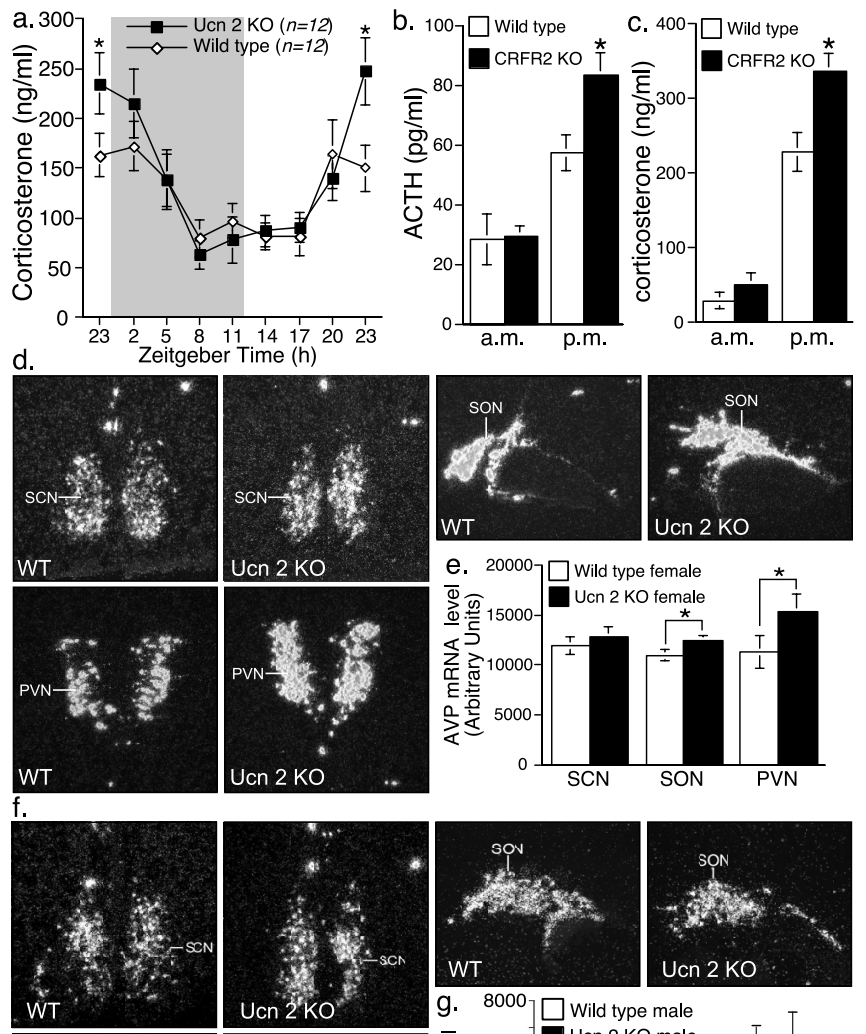
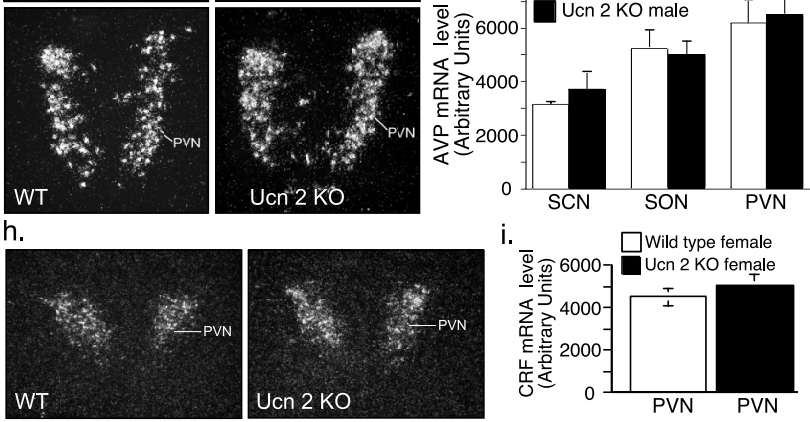

Figure 4. Elevated corticosterone levels in female Ucn-2 null mice during the light/dark cycle transition interphase and increase in hypothalamic AVP expression. $\boldsymbol{a}, \mathrm{A} 24 \mathrm{~h}$ corticosterone profile for female $U c n-2$ null and WT mice showed elevated levels in mutant females during the interphase light/dark cycle transition. Gray shading indicates the time of lights off. $\boldsymbol{b}, \boldsymbol{c}$, Basal (prestress) ACTH (b) and corticosterone (c) plasma levels at 7:00 A.M. (a.m.) and 5:00 P.M. (p.m.) in female (RFR2 mutant mice and WT littermates. Elevated ACTH and corticosterone levels were observed during the evening sampling. $\boldsymbol{d}-\boldsymbol{g}$, Representative dark-field photomicrographs $(\boldsymbol{d}, \boldsymbol{f})$ and semiquantitative analysis $(\boldsymbol{e}, \boldsymbol{g})$ showing in situ hybridization for hypothalamic AVP in WT and $U \boldsymbol{c n}-2$ null female $(\boldsymbol{d}, \boldsymbol{e})$ or male $(\boldsymbol{f}, \boldsymbol{g})$ mice. The AVP mRNA expression in the hypothalamic SON and PVN are significantly increased in mutant females, but not male, compared with WT littermates mice. $\boldsymbol{h}, \boldsymbol{i}$, Representative dark-field photomicrographs $(\boldsymbol{h})$ and semiquantitative analysis (i) showing in situ hybridization for CRF in the PVN of WT and Ucn-2 null female mice. Note that $U c n-2$ mutant mice show no significant differences in CRF mRNA expression in the PVN compared with WT littermates. SCN, Suprachiasmatic nucleus; ${ }^{*} p<0.05$ vs WT mice.

the HPA axis, we investigated the activity of HPA axis in these mice. The possible roles of Ucn-2 on basal HPA axis activity and the response to stress in both male and female null or WT mice were examined. The basal (prestress) ACTH and corticosterone levels were determined, and, interestingly, the evening (nocturnal) ACTH and corticosterone levels were higher in female, but not male, mutant mice relative to wild-type littermates (Fig. $3 a, b)$. These differences were not observed in ovariectomized females, indicating a possible involvement of acute estrogen in ef-
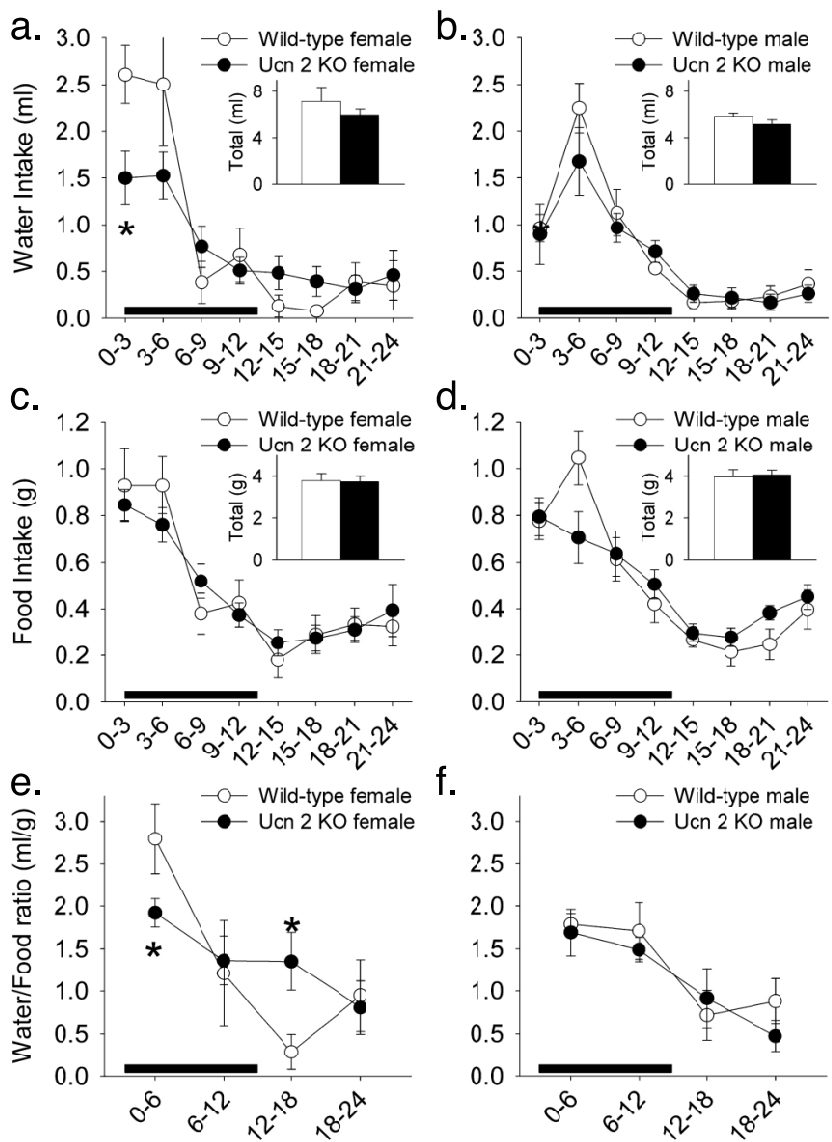

d.
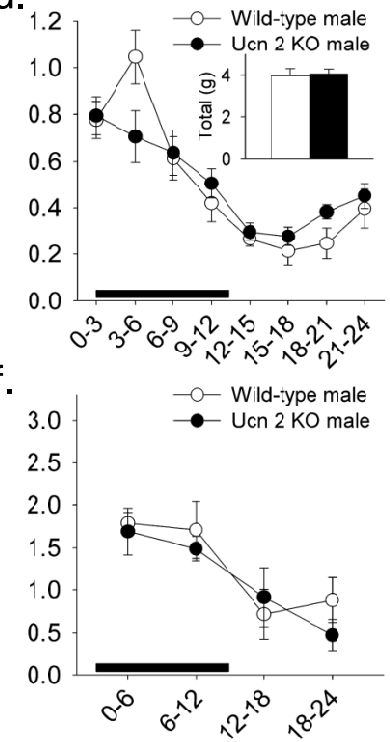

Time after dark cycle onset (hr)

Time after dark cycle onset (hr)

Figure 5. Blunted circadian amplitude of spontaneous water intake in female Ucn-2 mutant mice. $\boldsymbol{a}, \boldsymbol{b}, \mathrm{A} 24 \mathrm{~h}$ profile of water intake showed decreased peak water intake at the onset of the dark cycle and a trend for increased water intake at the diurnal nadir in female, but not male, Ucn-2 null mice. $\boldsymbol{c}, \boldsymbol{d}$, In contrast, the circadian profile of eating was not reliably altered in Ucn-2 null mutant mice of either sex. $\boldsymbol{e}, \boldsymbol{f}$, Female, but not male, $U \mathbf{c n}-2$ null mutant mice showed a flattening of the circadian rhythm of the water/food ratio, in which rodents typically drink in greater quantities relative to food during the nocturnal compared with diurnal cycles. Split-plot ANOVA revealed significant genotype $\times$ time interactions for the time course of drinking $\left(F_{(7,70)}=2.17 ; p<0.05\right)$ and water/food ratios $(p<0.05)$ in female, but not male, mice. Table 1 further quantifies differences in the circadian profile of ingestion using cosinor analysis. Data are displayed as the mean \pm SEM, and the black bar represents the dark cycle. ${ }^{*} p<0.05$ vs WT condition (Student's $t$ test).

fects of Ucn-2 deficiency (Fig. 3a,b). To examine the response of the HPA axis to stress, animals were subjected to 2 or $10 \mathrm{~min}$ of restraint stress. No significant differences in ACTH or corticosterone levels were observed between mutant and control mice subjected to this stress paradigm (Fig. $3 c, d$ ). It is interesting to note that OVX females showed lower basal corticosterone levels during the evening sampling (Fig. 3b), similar to those of the males, whereas their stress-induced corticosterone secretion resembled that of intact females (i.e., higher than males) (Fig. 3d). These data suggest that circulating estrogen contributes to the nocturnal basal corticosterone peak in females but not to stress-induced corticosterone release. To further investigate these gender differences, the basal plasma corticosterone levels in a separate set of female Ucn-2 null mice and WT littermates were determined across the circadian cycle. The $24 \mathrm{~h}$ corticosterone profile showed elevated levels in Ucn-2 null females only during the interphase light/dark cycle transition (Fig. 4a). A similar phenotype was observed in CRFR2 null female mice (Bale et al., 2000) compared 
Table 1. Cosinor analysis of the circadian rhythm of ingestion in Ucn-2 knock-out mice and their wild-type littermates

\begin{tabular}{|c|c|c|c|c|}
\hline & \multicolumn{2}{|l|}{ Female } & \multicolumn{2}{|l|}{ Male } \\
\hline & Wild type & Ucn-2 K0 & Wild type & Ucn-2 K0 \\
\hline \multicolumn{5}{|l|}{ Water intake } \\
\hline Amplitude ( $\mu \mathrm{l} / \mathrm{h})$ & $383 \pm 54$ & $234 \pm 24^{*}$ & $254 \pm 42$ & $201 \pm 58$ \\
\hline MESOR ( $\mu \mathrm{l} / \mathrm{h})$ & $304 \pm 54$ & $254 \pm 23$ & $206 \pm 26$ & $215 \pm 40$ \\
\hline $\operatorname{Peak}(\mu \mathrm{l} / \mathrm{h})$ & $686 \pm 101$ & $488 \pm 28^{*}$ & $462 \pm 65$ & $415 \pm 93$ \\
\hline Nadir ( $\mu \mathrm{l} / \mathrm{h})$ & $-79 \pm 42$ & $19 \pm 38$ & $-47 \pm 30$ & $14 \pm 37$ \\
\hline Acrophase (h after dark onset) & $3.6 \pm 0.5$ & $3.9 \pm 1.1$ & $5.9 \pm 0.1$ & $4.6 \pm 1.4$ \\
\hline Cosinor fit $(r)$ & $0.75 \pm 0.05$ & $0.73 \pm 0.07$ & $0.83 \pm 0.02$ & $0.76 \pm 0.06$ \\
\hline \multicolumn{5}{|l|}{ Food intake } \\
\hline Amplitude (mg/h) & $116 \pm 16$ & $102 \pm 11$ & $124 \pm 24$ & $102 \pm 6$ \\
\hline MESOR (mg/h) & $163 \pm 12$ & $160 \pm 12$ & $163 \pm 12$ & $186 \pm 19$ \\
\hline Peak (mgl/h) & $280 \pm 6$ & $262 \pm 18$ & $287 \pm 32$ & $288 \pm 17$ \\
\hline Nadir (mg/h) & $47 \pm 28$ & $58 \pm 15$ & $40 \pm 20$ & $83 \pm 21$ \\
\hline Acrophase (h after dark onset) & $3.7 \pm 0.8$ & $3.5 \pm 0.7$ & $4.6 \pm 0.6$ & $3.5 \pm 0.8$ \\
\hline Cosinor fit $(r)$ & $0.78 \pm 0.07$ & $0.85 \pm 0.04$ & $0.90 \pm 0.02$ & $0.90 \pm 0.02$ \\
\hline
\end{tabular}

found in hypothalamic PVN expression of CRF in female mutant mice compared with WT littermates (Fig. 4f,g).

\section{Altered circadian regulation of} spontaneous drinking in female Ucn-2 mutant mice

Because neuroanatomical and pharmacological studies suggest that Ucn-2 might be involved in the regulation of ingestive behavior, we studied spontaneous palatable chow intake and drinking of Ucn-2 null and WT mice across the day using a procedure that automatically quantifies ingestion in relation to nose-poke operant responses. Ucn-2 KO mice did not differ from wild-type mice in the number of days required to achieve stable, ad libitum levels of intake under test conditions, indicating
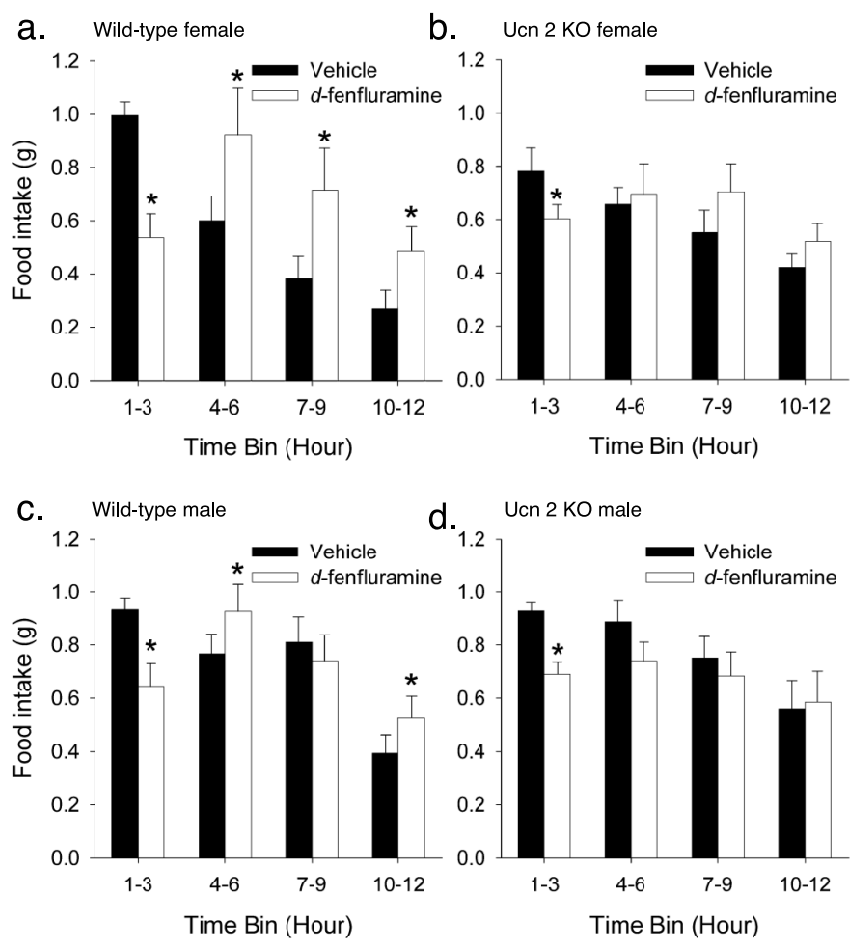

Figure 6. Altered effect of $d$-fenfluramine on food intake in Ucn-2 null mice. $\boldsymbol{a}$, c, Pretreatment with $d$-fenfluramine $(2 \mathrm{mg} / \mathrm{kg}$, i.p.) produced a characteristic acute hypophagic response in WT mice that was followed by hyperphagia, perhaps compensatory, relative to vehicle (10 $\mathrm{ml} / \mathrm{kg} 0.9 \%$ saline) conditions. $\boldsymbol{b}, \boldsymbol{d}, U(\mathrm{cn}-2$ null mutant mice did not exhibit the delayed postfenfluramine hyperphagia, and female null mutant mice exhibited a smaller hypophagic response than WT mice. Effects were reflected in significant genotype $X$ drug and genotype $X$ drug $\times$ time interactions. Data are expressed as the mean \pm SEM. ${ }^{*} p<0.05$ versus vehicle ( post hoc within-subject Student's $t$ test).

with WT littermates (Fig. 4b,c). These results indicate that the CRFR2 selective ligand Ucn-2 may modulate the amplitude of ACTH and corticosterone daily peaks in females. To further explore the possible mechanism mediating these differences, AVP (Fig. $4 d-g$ ) and CRF (Fig. 4h,i) mRNA levels in hypothalamic nuclei were determined. In situ hybridization revealed increased hypothalamic AVP in the PVN and SON of female (Fig. $4 d, e$ ), but not male (Fig. 4f,g) Ucn-2 null mice, implying a possible involvement of AVP in mediating these differences. No differences were intact acquisition of appetitive operant responding. Neither male nor female Ucn-2 mice differed in cumulative daily food or water intake from their respective littermates (Fig. $5 a-d$, insets), and we observed no consistent genotype differences in body weight in mice maintained on the precision-pelleted or extruded chow diets (data not shown).

Ucn-2 deficiency did not change the degree to which biorhythms of eating and drinking were circadian in nature, because the average cosinor goodness of fit was similar across genotypes (Table 1). Mice also did not differ according to genotype in the acrophase for food or water intake, which indicates the time of the dark cycle at which peak ingestion occurred (Table 1). However, as quantified by cosinor analyses (Table 1) and illustrated in Figure 5, female null mutant mice differed significantly from WT littermates in their pattern of drinking across the day. Ucn-2 KO females showed a significantly blunted peak of early nocturnal drinking and tended to drink more at the diurnal nadir of drinking, such that they had a significantly reduced amplitude of the circadian rhythm for drinking (Table 1, Fig. 5a). The biorhythm of eating was not altered (Table 1, Fig. $5 c$ ), so changes were reflected in a blunting of the rhythm of the water-to-food ratio in female Ucn-2 mutant mice (Fig. 5e,f), in which rodents normally exhibit proportionally more drinking during nocturnal than diurnal phases in relation to osmotic challenges, such as feeding (Patchev and Almeida, 1998; Tanaka et al., 2003; Kudielka and Kirschbaum, 2005; Zorrilla et al., 2005).

\section{Altered effect of $d$-fenfluramine on food intake in $U c n$-2 null mice}

In addition to basal ingestion, feeding responses of $U c n-2$ null mice to environmental or pharmacological challenges were also studied. Ucn-2 null mice showed a normal feeding response to $24 \mathrm{~h}$ food deprivation. Male and female mice of both genotypes showed similar, significant increases in food intake during the first refeeding hour. Female, but not male, mice of both genotypes continued to show similarly increased cumulative intake $24 \mathrm{~h}$ after refeeding (data not shown). Ucn-2 null mice also displayed a normal acute anorectic response to a stressor (intraperitoneal saline injection), observed in significant time $\times$ stress interactions $\left(F_{(3,33)}=5.96\right.$; $\left.p<0.005\right)$, with no main or interaction effect of genotype. However, the effects of systemic $d$-fenfluramine, an indirect serotonin agonist, on food intake were altered in Ucn-2 null mice, as indicated by a significant drug $\times$ genotype $\times$ time interaction in females $\left(F_{(3,30)}=5.39\right.$; 
$p<0.005)$ and significant drug $\times$ genotype $\left(F_{(1,11)}=6.08 ; p<0.05\right)$ and drug $\times$ genotype $X$ time interactions in males $\left(F_{(3,33)}=3.17 ; p<0.05\right)$. Fenfluramine decreased intake of $U c n-2 \mathrm{KO}$ females less than that of wild-type females during the first 3 posttreatment hours (reductions for WT, $0.46 \pm 0.05 \mathrm{~g}$ vs Ucn-2 KO, $0.18 \pm$ $0.06 \mathrm{~g}$, or an average of $47 \mathrm{vs} 19 \%$ of vehicle intake, respectively; $p=0.002$ ), as reflected in a drug $\times$ genotype interaction within the $0-3 \mathrm{~h}$ bin $\left(F_{(1,10)}=10.95 ; p<\right.$ 0.01 ) (Fig. $6 a, b)$. After the initial $3 \mathrm{~h}$ anorectic period, both male and female mutant mice exhibited a blunted postanorexia compensatory hyperphagia (Fig. $6 a-d)$. Intake of fenfluramine-treated wild-type female mice during this period (from 3 to $12 \mathrm{~h}$ ) significantly exceeded that under vehicle conditions by $0.88 \pm 0.36 \mathrm{~g}$ $(p<0.05$ vs 0$)$, whereas that of fenfluramine-treated mutant mice was not reliably greater than vehicle conditions $[0.29 \pm 0.23(\mathrm{NS})$ vs $0(p=0.01)$ vs WT difference]. The post-fenfluramine hyperphagia (3-12 h) of female mutant mice was $0.42 \mathrm{~g}$ greater than their initial anorectic response $(0-3 \mathrm{~h})$, whereas that of wildtype mice was only 0.11 g greater, suggesting that differences in the post-anorexia phase might not entirely result from the differential anorexia.

In contrast to females, male Ucn-2 $\mathrm{KO}$ did not differ from male WT mice in the magnitude of fenfluramine-induced anorexia (decrement of $0.24 \pm 0.06$ vs $0.29 \pm$ $0.09 \mathrm{~g}$ from vehicle intake, respectively; genotype difference was NS, both $p<0.05$ vs

$0)$. However, like females, Ucn-2 KO males differed from WT males during the subsequent post-anorectic phase, with male WT fully compensating for the anorectic phase during this period (significant increase of $0.22+0.06 \mathrm{~g}$ in WT, $p<0.02$ ), unlike $U c n-2 \mathrm{KO}$ male mice, which tended to reduce intake further (decrease of $0.19 \pm 0.11 \mathrm{~g}$ in $U c n-2 \mathrm{KO}, p<0.01$ for genotype effect) (Fig. $6 c, d$ ).

\section{Antidepressant-like phenotype of Ucn-2 null mice in the forced-swim and tail-suspension tests}

$U c n$-2-deficient female mice were less immobile than their WT littermates in the modified FST, as reflected in a main effect of genotype (Fig. $7 a, b)\left(F_{(1,20)}=5.90 ; p<0.03\right)$, an antidepressantlike phenotype. Time course analysis (Fig. $7 a, b)$ revealed that Ucn-2 null females did not increase their immobility over the course of the session, in contrast to WT mice. The reduced immobility resulted mostly from an increase in swimming behavior, a behavior pharmacologically linked to altered serotonergic functioning, because five (50\%) Ucn-2 null females had swimming counts $>1.96 \mathrm{SD}(p<0.05)$ greater than the control mean during the last $10 \mathrm{~min}$ of the session. Only one $U c n-2$ null female climbed, rather than swum, significantly more; she climbed during $92 \%$ of the behavior ratings, $>10$ SD beyond the control mean. In contrast, male mice did not differ according to genotype in the modified FST, with both $U_{c n}-2$ null and WT mice becom- ing significantly more immobile across the 15 min session. Female, but not male, Ucn-2 null mice also were less immobile in the tail-suspension test, again an antidepressant-like phenotype (Fig. $7 c$ ). The altered performance of female $U c n-2$ null mice in tests of antidepressant activity was behaviorally specific, because Ucn-2 null mutant mice did not differ in their anxiety-like behavior in the elevated plus maze (Fig. $7 d, e$ ) or light/dark box tests (Fig. $7 \mathrm{~h}$ ), nor did they differ reliably in their levels of spontaneous locomotor activity across the circadian cycle (Fig. $8 a-d$ ) or in their levels of exploratory/locomotor activity during anxiety testing (Fig. $7 f, g, i)$. To abolish generalized learning deficits as an explanation for the differences observed at the forced-swim test, we performed a cued contextual fear conditioning test. There were no differences between the genotypes in freezing behavior during the habituation or conditioning trials (Fig. $8 e-h$ ) and in the context test or the conditioned stimulus test (Fig. $8 i-l$ ).

\section{Brain expression of CRF family peptides and receptors is} altered in Ucn-2 null mutant mice

To explore alterations in the expression of CRF family ligands and receptors in $U c n-2$ null mutants, we used in situ hybridization to determine the levels CRF, Ucn-3, Ucn-1, CRFR1, and CRFR2 in these mice (Fig. 9). We observed an increase in CRF mRNA levels in the bed nucleus of the stria terminalis (BNST) and the central nucleus of amygdala (CeA) of mutant mice (Fig. 

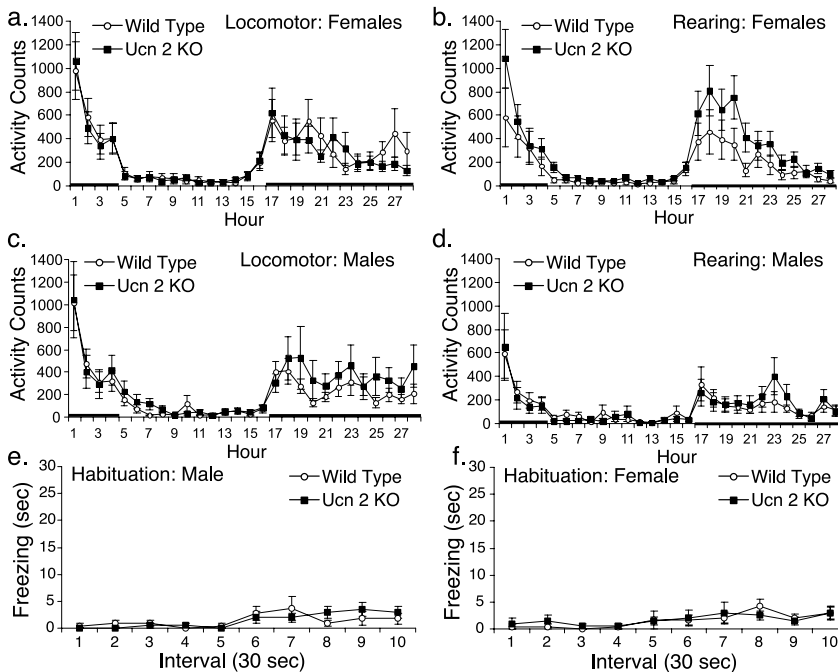

d.
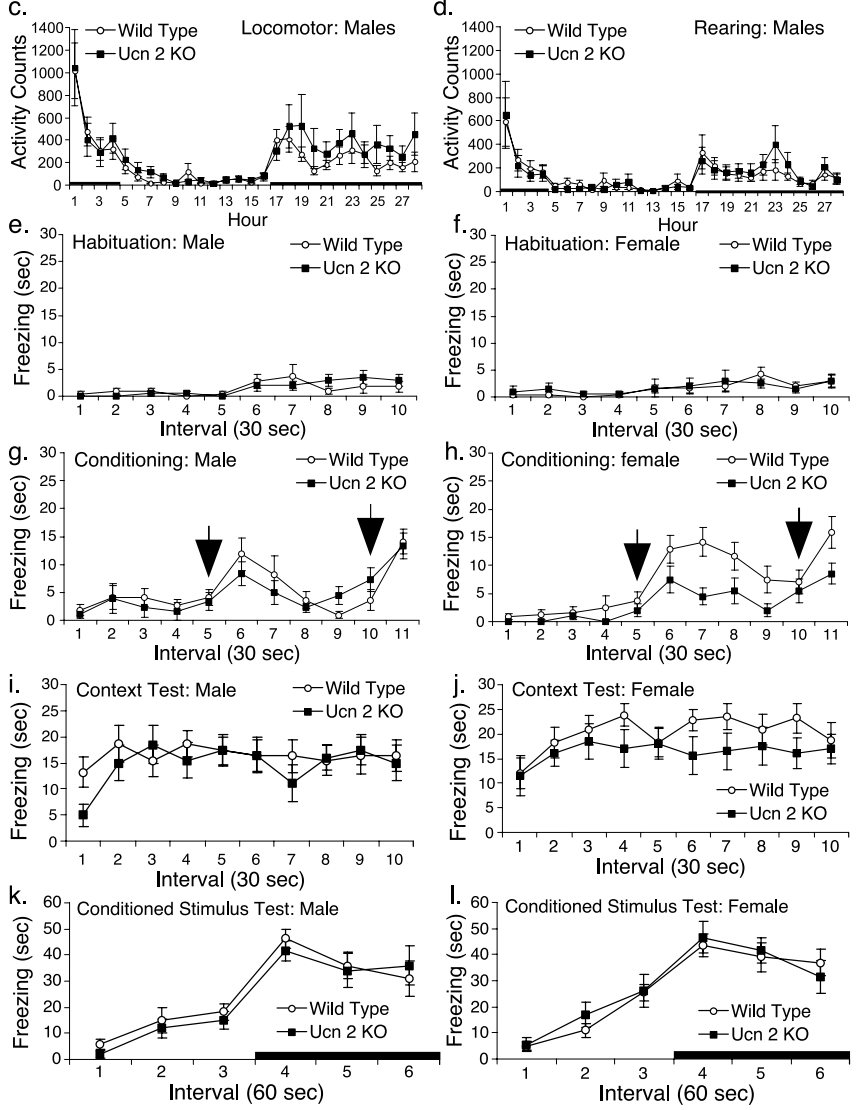

Figure 8. Locomotor activity and rearing behavior and contextual and cued conditioning in Ucn-2 null and WT mice. $\boldsymbol{A}-\boldsymbol{d}$, Twenty-eight hour horizontal (locomotor; $\boldsymbol{a}, \boldsymbol{b}$ ) activity or vertical (rearing; $\boldsymbol{c}, \boldsymbol{d})$ behavior for $U \boldsymbol{c n}-2$ null and WT female $(\boldsymbol{a}, \boldsymbol{c})$ or male $(\boldsymbol{b}, \boldsymbol{d})$ mice. Data are displayed as the mean \pm SEM. The black bar represents the dark cycle. $\boldsymbol{e}-\boldsymbol{I}$, All four trials are shown (habituation, $\boldsymbol{e}, \boldsymbol{f}$; conditioning, $\boldsymbol{g}, \boldsymbol{h}$; context test, $\boldsymbol{i}, \boldsymbol{j}$, and conditioned stimulus, $\boldsymbol{k}, \boldsymbol{I}$ ) for male $(\boldsymbol{e}, \boldsymbol{g}, \boldsymbol{i}, \boldsymbol{k})$ and female $(\boldsymbol{f}, \boldsymbol{h}, \boldsymbol{j}, \boldsymbol{I})$ mice. The arrows on the conditioning trial graphs represent the onset of the $2 \mathrm{~s}$ shock. Data are expressed as the mean \pm SEM of the time (seconds) spent freezing within the time interval indicated on the horizontal axis.

$9 a, b)$. Surprisingly, we observed a reduction in mRNA levels of Ucn-3, which, like Ucn-2, is a specific ligand for CRFR2, in the median preoptic nucleus (MPO) and perifornical area $(\mathrm{PeF})$ of mutant mice (Fig. $9 c, d$ ). We also observed an increase in the expression of the cognate receptor for Ucn-2, CRFR2, in the lateral septum (LS), dorsal raphe (DR), and BNST (Fig. 9i,j). We found no difference in Ucn-1 (Fig. 9e,f) or CRFR1 (Fig. 9g,h) mRNA expression between Ucn-2 null mutants and WT littermates.

\section{Discussion}

The main findings of the present study are that, relative to WT littermates, female, but not male, mice null for Ucn-2 show increased basal corticosterone and ACTH levels at the light/dark interphase and an antidepressant-like behavioral phenotype in animal models sensitive to antidepressant action. Using in situ hybridization studies, we demonstrated an increase in hypothalamic AVP expression in female, but not male, Ucn-2-knock-out mice, which also positively correlated with changes in the control of water intake. The results indicate that endogenous Ucn-2 may modulate the daily rhythm of basal HPA axis activity and fluid intake and that Ucn-2 also may reduce the persistence of active behavioral responding to sustained, inescapable stressors.

The HPA axis exhibits two distinct activation patterns, a stress-dependent activation after real or perceived challenges and a circadian-dependent release, which is essential for maintaining normal energy balance. In nocturnal animals, plasma glucocorticoid levels are low in the morning and peak near the onset of darkness. The corticosterone peak at the end of a period of inactivity and fasting may serve to prepare the animal for the coming period of increased activity by mobilizing stored energy, stimulating carbohydrate and fat intake and initiating food searching behavior. Pronounced sex differences exist in both stress and circadian-dependent activation, whereby females exhibit a greater magnitude and duration of HPA response to stressors and higher plasma concentration of ACTH and corticosterone throughout the daily rhythms with pronounced differences at the peak of the circadian rhythm (for review, see Rhodes and Rubin, 1999; Kudielka and Kirschbaum, 2005). CRF and AVP were proposed as the principal neuronal signals controlling diurnal ACTH and glucocorticoid rhythms (Patchev and Almeida, 1998; Tanaka et al., 2003). Ucn-2 is expressed by several hypothalamic nuclei, with highest levels of expression in the magnocellular neurons of the PVN (Reyes et al., 2001). A recent study demonstrated a strong induction of $U \mathrm{cn}-2 \mathrm{mRNA}$ expression in the parvocellular region of the PVN after immobilization stress and dramatic Ucn-2 mRNA expression in the magnocellular division of the PVN after water deprivation (Tanaka et al., 2003). Using doublelabel in situ hybridization, Tanaka et al. showed that Ucn-2 is colocalized with $\sim 45 \%$ of CRF-expressing cells in the parvocellular part of the PVN and with most of the AVP neurons in the magnocellular part of the PVN after immobilization and water deprivation paradigms, respectively. Female, but not male, Ucn2-deficient mice showed an increase in AVP expression in hypothalamic magnocellular neurons, which may contribute to the increased nocturnal ACTH and corticosterone levels in these female mice.

Male or female $U c n$-2-deficient mice showed no differences in cumulative daily food or water intake from their respective littermates; however, female mutant mice differed significantly from wild-type littermates in their pattern of drinking across the day. Rodents normally exhibit proportionally more drinking during nocturnal than diurnal phases in relation to osmotic challenges, such as feeding (Johnson and Johnson, 1990a,b; Johnson et al., 2003; Zorrilla et al., 2005). As noted above, the colocalization of Ucn-2 and AVP in the magnocellular neurons of the PVN, its regulation by water deprivation (Tanaka et al., 2003), and the increase expression of AVP in the PVN and SON nuclei of the female Ucn-2-deficient mice may suggest a possible role for $\mathrm{Ucn}-2$ in modulating fluid intake under specific osmotic challenges. Because CRFR2 is expressed in the PVN, Ucn-2 may regulate AVP expression or secretion in an autocrine or/and paracrine manner in the magnocellular PVN. It is interesting to note that, from an evolutionary perspective, stress regulation in vertebrates is associated with an ancient endocrine osmoregulation system in insects, and this system has expanded and diverged to provide a more intricate system for stress regulation in vertebrates (Chang and Hsu, 2004). It is conceivable that a possible role for the Ucn-2/CRFR2 system is to modulate osmoregulation via the magnocellular PVN and SON during challenges to bodyfluid homeostasis. 
Ample evidence supports the role of the CRF family of peptide and receptors in stress-related endocrine, autonomic, and behavioral disorders. Chronic stress and dysregulation of the homeostatic stress response is a proposed mechanism that may accelerate psychopathologic disease processes and lead to or precipitate mood disorders (Earls, 1987; Nestler et al., 2002). Accordingly, chronic hyperactivation of the CRF system has been linked to the development of major depression (for review, see Holsboer, 1999). Localization of the CRF family of peptide and receptors within brain regions associated with the neural circuitry of depression supports an involvement of CRF/urocortin pathways in the pathogenesis of this disease. Recently, we demonstrated that male and female CRFR2 null mice showed a significant increase in depression-like behaviors in the modified Porsolt swim test but a sexually dichotomous sensitivity to the CRFR1-specific antagonist antalarmin (Bale and Vale, 2003). Increased CRF levels in the central nucleus of the amygdala and increased Ucn-1 levels in the Edinger Westphal nucleus were observed in CRFR2-deficient mice and proposed as possible mechanisms that facilitated depression-like behaviors via an increased degree of CRFR1 stimulation (Bale and Vale, 2003). In contrast, our current results show that female Ucn-2-deficient mice were less immobile than WT littermates in modified forced-swim and tailsuspension tests, an antidepressant-like phenotype. Male WT and null mutant mice did not differ in these tests. Ucn-2 null and WT mice did not differ in tests of locomotor activity, anxiety-like behaviors, appetitive operant learning, or aversive learning, demonstrating a behaviorally specific antidepressant-like phenotype. Previous studies using the modified forced-swim test have demonstrated that catecholaminergic agents may decrease immobility by increasing climbing, whereas serotonergic agents may decrease immobile time by increasing swimming (Detke et al., 1995, 1996; Cryan et al., 2002). Insofar as the reduced immobility of female Ucn-2deficient mice resulted primarily from an increase in swimming behavior, their antidepressant-like phenotype may be linked to altered serotonergic neurotransmission. Interestingly, female, but not male, 5 - $\mathrm{HT}_{1 \mathrm{~B}}$-deficient mice also selectively show reduced immobility in the forced-swim and tail-suspension tests (Jones and Lucki, 2005), putatively through a mechanism involving disinhibition of 5-HT signaling. Furthermore, several other studies have demonstrated a differential sensitivity of females to genetic deletion or polymorphisms of modulators of serotonin function (Bouali et al., 2003; Cornelissen et al., 2005; Jones and Lucki, 2005).

Also suggesting altered serotonergic function, food intake of Ucn-2-deficient mice differed from wild-type littermates after administration of $d$-fenfluramine, a drug that blocks the reuptake of serotonin and stimulates its release. Female Ucn-2-deficient mice showed attenuation of the initial anorectic response, and both male and female mutant mice exhibited an absence of the post-anorexia compensatory hyperphagia. As reported previously, $d$-fenfluramine induced Fos-like immunoreactivity in a dose-dependent manner in many brain regions associated with energy homeostasis (Heisler et al., 2002), including the arcuate and paraventricular nuclei of the hypothalamus. These hypothalamic regions are proposed targets for $d$-fenfluramine anorexia because they receive direct input from 5-HT dorsal raphe nucleus (DRN) neurons (Heisler et al., 2002) and because hypothalamic $5-\mathrm{HT}_{2 \mathrm{C}}$ receptors are thought to mediate the hypophagic effects of $d$-fenfluramine in mice (Hewitt et al., 2002; Lee et al., 2004). The DRN contains a high density of CRFR2 and lower levels of CRFR1 and receives CRF projections from a variety of forebrain and limbic structures, including the amygdala and BNST. A 
growing body of evidence supports the hypothesis that the activation of CRFR1 inhibits 5-HT release, whereas CRFR2 activation leads to excitatory effects (Kirby et al., 2000; Valentino et al., 2001; Hammack et al., 2002, 2003). In addition to CRF, Ucn-2, which is highly expressed in the locus ceruleus nucleus, may innervate the DRN via a known reciprocal connection between these two brain regions (Kim et al., 2004). Moreover, intra-DRN administration of Ucn-2 dose dependently increased 5-HT efflux in the basolateral amygdala (Amat et al., 2004) and caused behavioral changes associated with inescapable tail shock, which were effective at doses 100-fold lower than those required for CRF (Hammack et al., 2003). The fact that the CRFR2 is highly expressed in the DRN, the observed alteration in the circadian HPA axis, antidepressant-like behaviors sensitive to selective serotonin reuptake inhibitor action, and sensitivity to $d$-fenfluramine collectively suggests an interplay of $U \mathrm{cn}-2$ tone with serotonergic signaling.

The interpretation of such complex data in a developmental knock-out model are difficult because of possible compensatory mechanisms that may change the physiological or behavioral phenotype of the mature mice. Furthermore, complete deletion of Ucn-2 may complicate the interpretation of the observed phenotype because of diverse contributions of Ucn-2 expressed by different brain nuclei. Caution should also be used when interpreting studies that focus on the gender differences originating from a deletion of a single gene in the brain, because physiological and behavioral responses are often associated with several neurotransmitter systems working in tandem. Future studies involving nuclei-specific knockdown or overexpression of Ucn-2 may further elucidate the importance of this neuropeptide as a modulator of basal or stress-related physiological and behavioral responses.

\section{References}

Amat J, Tamblyn JP, Paul ED, Bland ST, Amat P, Foster AC, Watkins LR, Maier SF (2004) Microinjection of urocortin 2 into the dorsal raphe nucleus activates serotonergic neurons and increases extracellular serotonin in the basolateral amygdala. Neuroscience 129:509-519.

Arborelius L, Owens MJ, Plotsky PM, Nemeroff CB (1999) The role of corticotropin-releasing factor in depression and anxiety disorders. J Endocrinol 160:1-12.

Bale TL, Vale WW (2003) Increased depression-like behaviors in corticotropin-releasing factor receptor-2-deficient mice: sexually dichotomous responses. J Neurosci 23:5295-5301.

Bale TL, Vale WW (2004) CRF and CRF receptors: role in stress responsivity and other behaviors. Annu Rev Pharmacol Toxicol 44:525-557.

Bale TL, Contarino A, Smith GW, Chan R, Gold LH, Sawchenko PE, Koob GF, Vale WW, Lee KF (2000) Mice deficient for corticotropin-releasing hormone receptor-2 display anxiety-like behaviour and are hypersensitive to stress. Nat Genet 24:410-414.

Bouali S, Evrard A, Chastanet M, Lesch KP, Hamon M, Adrien J (2003) Sex hormone-dependent desensitization of 5-HT1A autoreceptors in knockout mice deficient in the 5-HT transporter. Eur J Neurosci 18:2203-2212.

Bourin M, Hascoet M (2003) The mouse light/dark box test. Eur J Pharmacol 463:55-65.

Chang CL, Hsu SY (2004) Ancient evolution of stress-regulating peptides in vertebrates. Peptides 25:1681-1688.

Chen A, Blount A, Vaughan J, Brar B, Vale W (2004) Urocortin II gene is highly expressed in mouse skin and skeletal muscle tissues: localization, basal expression in corticotropin-releasing factor receptor (CRFR) 1 - and CRFR2-null mice, and regulation by glucocorticoids. Endocrinology 145:2445-2457.

Chen R, Lewis KA, Perrin MH, Vale WW (1993) Expression cloning of a human corticotropin-releasing-factor receptor. Proc Natl Acad Sci USA 90:8967-8971.

Chen SA, O'Dell LE, Hoefer ME, Greenwell TN, Zorrilla EP, Koob GF. (2006) Unlimited access to heroin self-administration: independent mo- tivational markers of opiate dependence. Neuropsychopharmacology, in press.

Chrousos GP, Gold PW (1992) The concepts of stress and stress system disorders. Overview of physical and behavioral homeostasis. JAMA 267:1244-1252.

Contarino A, Baca L, Kennelly A, Gold LH (2002) Automated assessment of conditioning parameters for context and cued fear in mice. Learn Mem 9:89-96.

Cornelissen LL, Brooks DP, Wibberley A (2005) Female, but not male, serotonin reuptake transporter (5-HTT) knockout mice exhibit bladder instability. Auton Neurosci 122:107-110.

Cryan JF, Markou A, Lucki I (2002) Assessing antidepressant activity in rodents: recent developments and future needs. Trends Pharmacol Sci 23:238-245.

Cryan JF, Mombereau C, Vassout A (2005) The tail suspension test as a model for assessing antidepressant activity: review of pharmacological and genetic studies in mice. Neurosci Biobehav Rev 29:571-625.

de Kloet ER, Joels M, Holsboer F (2005) Stress and the brain: from adaptation to disease. Nat Rev Neurosci 6:463-475.

Detke MJ, Lucki I (1996) Detection of serotonergic and noradrenergic antidepressants in the rat forced swimming test: the effects of water depth. Behav Brain Res 73:43-46.

Detke MJ, Rickels M, Lucki I (1995) Active behaviors in the rat forced swimming test differentially produced by serotonergic and noradrenergic antidepressants. Psychopharmacology 121:66-72.

Earls F (1987) Sex differences in psychiatric disorders: origins and developmental influences. Psychiatr Dev 5:1-23.

Hammack SE, Richey KJ, Schmid MJ, LoPresti ML, Watkins LR, Maier SF (2002) The role of corticotropin-releasing hormone in the dorsal raphe nucleus in mediating the behavioral consequences of uncontrollable stress. J Neurosci 22:1020-1026.

Hammack SE, Schmid MJ, LoPresti ML, Der-Avakian A, Pellymounter MA, Foster AC, Watkins LR, Maier SF (2003) Corticotropin releasing hormone type 2 receptors in the dorsal raphe nucleus mediate the behavioral consequences of uncontrollable stress. J Neurosci 23:1019-1025.

Heisler LK, Cowley MA, Tecott LH, Fan W, Low MJ, Smart JL, Rubinstein M, Tatro JB, Marcus JN, Holstege H, Lee CE, Cone RD, Elmquist JK (2002) Activation of central melanocortin pathways by fenfluramine. Science 297:609-611.

Hewitt KN, Lee MD, Dourish CT, Clifton PG (2002) Serotonin 2C receptor agonists and the behavioural satiety sequence in mice. Pharmacol Biochem Behav 71:691-700.

Holmes A, Heilig M, Rupniak NM, Steckler T, Griebel G (2003) Neuropeptide systems as novel therapeutic targets for depression and anxiety disorders. Trends Pharmacol Sci 24:580-588.

Holsboer F (1999) The rationale for corticotropin-releasing hormone receptor (CRH-R) antagonists to treat depression and anxiety. J Psychiatr Res 33:181-214.

Hsu SY, Hsueh AJ (2001) Human stresscopin and stresscopin-related peptide are selective ligands for the type 2 corticotropin-releasing hormone receptor. Nat Med 7:605-611.

Johnson RF, Johnson AK (1990a) Light-dark cycle modulates drinking to homeostatic challenges. Am J Physiol 259:R1035-R1042.

Johnson RF, Johnson AK (1990b) Light/dark cycle modulates food to water intake ratios in rats. Physiol Behav 48:707-711.

Johnson RF, Beltz TG, Thunhorst RL, Johnson AK (2003) Investigations on the physiological controls of water and saline intake in C57BL/6 mice. Am J Physiol Regul Integr Comp Physiol 285:R394-R403.

Jones MD, Lucki I (2005) Sex differences in the regulation of serotonergic transmission and behavior in 5-HT receptor knockout mice. Neuropsychopharmacology 30:1039-1047.

Kim MA, Lee HS, Lee BY, Waterhouse BD (2004) Reciprocal connections between subdivisions of the dorsal raphe and the nuclear core of the locus coeruleus in the rat. Brain Res 1026:56-67.

Kirby LG, Rice KC, Valentino RJ (2000) Effects of corticotropin-releasing factor on neuronal activity in the serotonergic dorsal raphe nucleus. Neuropsychopharmacology 22:148-162.

Kishimoto T, Pearse II RV, Lin CR, Rosenfeld MG (1995) A sauvagine/ corticotropin-releasing factor receptor expressed in heart and skeletal muscle. Proc Natl Acad Sci USA 92:1108-1112.

Koob GF, Heinrichs SC (1999) A role for corticotropin releasing factor and urocortin in behavioral responses to stressors. Brain Res 848:141-152. 
Kudielka BM, Kirschbaum C (2005) Sex differences in HPA axis responses to stress: a review. Biol Psychol 69:113-132.

Lee MD, Somerville EM, Kennett GA, Dourish CT, Clifton PG (2004) Reduced hypophagic effects of $d$-fenfluramine and the 5-HT2C receptor agonist mCPP in 5-HT1B receptor knockout mice. Psychopharmacology 176:39-49.

Lentz MJ (1990) Time-series analysis-cosinor analysis: a special case. West J Nurs Res 12:408-412

Lewis K, Li C, Perrin MH, Blount A, Kunitake K, Donaldson C, Vaughan J, Reyes TM, Gulyas J, Fischer W, Bilezikjian L, Rivier J, Sawchenko PE, Vale WW (2001) Identification of urocortin III, an additional member of the corticotropin-releasing factor (CRF) family with high affinity for the CRF2 receptor. Proc Natl Acad Sci USA 98:7570-7575.

Li C, Vaughan J, Sawchenko PE, Vale WW (2002) Urocortin IIIimmunoreactive projections in rat brain: partial overlap with sites of type 2 corticotrophin-releasing factor receptor expression. J Neurosci 22:991-1001.

Lister RG (1987) The use of a plus-maze to measure anxiety in the mouse. Psychopharmacology 92:180-185.

Lovenberg TW, Liaw CW, Grigoriadis DE, Clevenger W, Chalmers DT, De Souza EB, Oltersdorf T (1995) Cloning and characterization of a functionally distinct corticotropin-releasing factor receptor subtype from rat brain. Proc Natl Acad Sci USA 92:836-840.

Nestler EJ, Barrot M, DiLeone RJ, Eisch AJ, Gold SJ, Monteggia LM (2002) Neurobiology of depression. Neuron 34:13-25.

Patchev VK, Almeida OF (1998) Gender specificity in the neural regulation of the response to stress: new leads from classical paradigms. Mol Neurobiol 16:63-77.

Perrin M, Donaldson C, Chen R, Blount A, Berggren T, Bilezikjian L, Sawchenko P, Vale W (1995) Identification of a second corticotropinreleasing factor receptor gene and characterization of a cDNA expressed in heart. Proc Natl Acad Sci USA 92:2969-2973.

Piccinelli M, Wilkinson G (2000) Gender differences in depression. Critical review. Br J Psychiatry 177:486-492.

Porsolt RD, Le Pichon M, Jalfre M (1977) Depression: a new animal model sensitive to antidepressant treatments. Nature 266:730-732.

Reyes TM, Lewis K, Perrin MH, Kunitake KS, Vaughan J, Arias CA, Hogenesch JB, Gulyas J, Rivier J, Vale WW, Sawchenko PE (2001) Urocortin II: a member of the corticotropin-releasing factor (CRF) neuropeptide family that is selectively bound by type 2 CRF receptors. Proc Natl Acad Sci USA 98:2843-2848.

Rhodes ME, Rubin RT (1999) Functional sex differences ("sexual diergism") of central nervous system cholinergic systems, vasopressin, and hypothalamic-pituitary-adrenal axis activity in mammals: a selective review. Brain Res Brain Res Rev 30:135-152.
Rivier C, Vale W (1983) Modulation of stress-induced ACTH release by corticotropin releasing factor, catecholamines and vasopressin. Nature 305:325-327.

Smith GW, Aubry JM, Dellu F, Contarino A, Bilezikjian LM, Gold LH, Chen R, Marchuk Y, Hauser C, Bentley CA, Sawchenko PE, Koob GF, Vale W, Lee KF (1998) Corticotropin releasing factor receptor 1-deficient mice display decreased anxiety, impaired stress response, and aberrant neuroendocrine development. Neuron 20:1093-1102.

Smolensky MH, Tatar SE, Bergman SA, Losman JG, Barnard CN, Dacso CC, Kraft IA (1976) Circadian rhythmic aspects of human cardiovascular function: a review by chronobiologic statistical methods. Chronobiologia 3:337-371.

Stenzel P, Kesterson R, Yeung W, Cone RD, Rittenberg MB, Stenzel-Poore MP (1995) Identification of a novel murine receptor for corticotropinreleasing hormone expressed in the heart. Mol Endocrinol 9:637-645.

Sunal R, Gumusel B, Kayaalp SO (1994) Effect of changes in swimming area on results of "behavioral despair test." Pharmacol Biochem Behav 49:891-896.

Sutton RE, Koob GF, LeMoal M, Rivier J, Vale WW (1982) Corticotropinreleasing factor $(\mathrm{CRF})$ produces behavioral activation in rats. Nature 297:331-333.

Tanaka Y, Makino S, Noguchi T, Tamura K, Kaneda T, Hashimoto K (2003) Effect of stress and adrenalectomy on urocortin II mRNA expression in the hypothalamic paraventricular nucleus of the rat. Neuroendocrinology 78:1-11.

Vale W, Spiess J, Rivier C, Rivier J (1981) Characterization of a 41-residue ovine hypothalamic peptide that stimulates secretion of corticotropin and beta-endorphin. Science 213:1394-1397.

Valentino RJ, Liouterman L, Van Bockstaele EJ (2001) Evidence for regional heterogeneity in corticotropin-releasing factor interactions in the dorsal raphe nucleus. J Comp Neurol 435:450-463.

Van Pett K, Viau V, Bittencourt JC, Chan RK, Li HY, Arias C, Prins GS, Perrin M, Vale W, Sawchenko PE (2000) Distribution of mRNAs encoding CRF receptors in brain and pituitary of rat and mouse. J Comp Neurol 428:191-212.

Vaughan J, Donaldson C, Bittencourt J, Perrin MH, Lewis K, Sutton S, Chan R, Turnbull AV, Lovejoy D, Rivier C, Sawchenko PE, Vale W (1995) Urocortin, a mammalian neuropeptide related to fish urotensin I and to corticotropin-releasing factor. Nature 378:287-292.

Zorrilla EP, Koob GF (2004) The therapeutic potential of $\mathrm{CRF}_{1}$ antagonists for anxiety. Expert Opin Investig Drugs 137:799-828.

Zorrilla EP, Inoue K, Fekete EM, Tabarin A, Valdez GR, Koob GF (2005) Measuring meals: structure of prandial food and water intake of rats. Am J Physiol Regul Integr Comp Physiol 288:R1450-R1467. 